\title{
Commentary
}

\section{WHY TALKING ABOUT "STATES' RIGHTS" CANNOT AVOID THE NEED FOR NORMATIVE FEDERALISM ANALYSIS: A RESPONSE TO PROFESSORS BAKER AND YOUNG}

\author{
ANN ALTHOUSE $\dagger$
}

\section{INTRODUCTION}

In an article provocatively titled Federalism: Some Notes on A National Neurosis, ${ }^{1}$ Edward L. Rubin and Malcolm Feeley diagnose the American concern about federalism as neurotic. Americans' ideas about the states are inappropriate and odd, Rubin and Feeley argue, but they do not seriously interfere with Americans' way of life. ${ }^{2}$ Judges and commentators express a fond regard for the states, but they tend to favor only the most modest judicial efforts at preserving local autonomy; they hem in their federalism doctrine so that it can do little to threaten what is, in fact, a profound commitment to national unity.

Lynn A. Baker and Ernest A. Young do not hedge. ${ }^{3}$ Unlike Rubin and Feeley's neurotics, who are burdened with an unnecessary obsession, but who do not let it interfere with their healthy pursuit of

Copyright (C) 2001 by Ann Althouse.

$\dagger$ Irma M. \& Robert W. Arthur-Bascom Professor of Law, University of Wisconsin Law School. This Essay is a response to Lynn A. Baker \& Ernest A. Young, Federalism and the Double Standard of Judicial Review, 51 DUKE L.J. 75 (2001), presented at the Constitution in Exile conference hosted by the Program in Public Law at Duke University School of Law on October 5-7, 2000. I would like to express my thanks to Chris Schroeder for inviting me to participate in this conference and to Professors Baker and Young for writing such a fascinating article on which to comment.

1. Edward L. Rubin \& Malcolm Feeley, Federalism: Some Notes on A National Neurosis, 41 UCLA L. REV. 903, 908 (1994).

2. Id.

3. Lynn A. Baker \& Ernest A. Young, Federalism and the Double Standard of Judicial Review, 51 DUKE L.J. 75, 78 (2001). 
national uniformity, Baker and Young have no intention of keeping their federalism under control. I suppose Rubin and Feeley would diagnose them as psychotic. But Baker and Young turn Rubin and Feeley's notion on its head: they-in effect-diagnose Americans with post-traumatic stress disorder. It is not that ideas about federalism fog their straight thinking; rather, it is that nightmares from the past debilitate them. Americans cannot contemplate state and local government autonomy without having flashbacks to the nation's history of slavery, segregation, and racism. As Baker and Young see it, this flood of bad memories is disabling Americans from thinking accurately about—dare we say it?—-states' rights. ${ }^{4}$

It is Baker and Young's assertion that that past is over, and that it is now safe to reap the benefits of real state autonomy. Part I of this Essay discusses Baker and Young's embrace of the term "states' rights" and examines whether it makes sense to equate the rights of states to the rights of individuals. Part II considers their contention that a "double standard" of constitutional interpretation exists and has a significant effect. Part III looks at their attack on the belief that Congress can protect state interests sufficiently. Ultimately, I conclude that there is no escape from the normative question: Will state autonomy do more harm than good? How this question is answered inevitably drives the thinking about whether to endorse stronger judicial enforcement of state autonomy and whether the label "states' rights" can be tolerated.

\section{Rights FOR StATES: ARE THEY LIKE RightS FOR INDIVIDUALS?}

Baker and Young boldly employ the inflammatory term "states' rights." ${ }^{, 5}$ Before reading their wonderfully assertive new article, I had thought the term states' rights survived only in the vocabulary of opponents of the Supreme Court's recent efforts on behalf of the states. ${ }^{6}$ "Federalism," I would have thought, is the term of choice for supporters of the Court's current jurisprudence. The term federalism

4. See id. at 143-49 ("To many, [the notion of states' rights] stands for an anachronistic (and immoral) preference for the race-based denial of essential individual rights ....").

5. Id. at $76,133$.

6. See Ann Althouse, On Dignity and Deference: The Supreme Court's New Federalism, 68 U. CIN. L. REV. 245, 245 \& n.2 (2000) (presenting a list of newspaper articles from 1999 in which "[t]he conservative side of the Supreme Court" is characterized as a group of "'States' Rights' adherents"). 
conjures up more functional and pragmatic ideas about the role of the states. In Younger v. Harris, ${ }^{7}$ Justice Black wrote of

a proper respect for state functions, a recognition of the fact that the entire country is made up of a Union of separate state governments, and a continuance of the belief that the National Government will fare best if the States and their institutions are left free to perform their separate functions in their separate ways. This, perhaps for lack of a better and clearer way to describe it, is referred to by many as "Our Federalism," and one familiar with the profound debates that ushered our Federal Constitution into existence is bound to respect those who remain loyal to the ideals and dreams of "Our Federalism." The concept does not mean blind deference to "States" Rights" any more than it means centralization of control over every important issue in our National Government and its courts .... [It] is a system in which there is sensitivity to the legitimate interests of both State and National Governments, and in which the National Government, anxious though it may be to vindicate and protect federal rights and federal interests, always endeavors to do so in ways that will not unduly interfere with the legitimate activities of the States. ${ }^{8}$

I often have admired this passage as a nice, if abstract, statement of American federalism. ${ }^{9}$ The idea is that the federal system is designed to work, and that things work best when separate institutions with different functions are given the independence to pursue their own policies in their own ways. Some things are done best at the state or local level, and, as to those things, it is good to design doctrines of constitutional law capable of controlling interference from the national level. ${ }^{10}$ Doctrine shaped with that sort of pragmatism can provide all the flexibility necessary to enable the national government to do everything that needs to be done at the national level. This is the

7. 401 U.S. 37 (1971).

8. Id. at 44 .

9. But then, I am one of Rubin and Feeley's "neurotics." See Rubin \& Feeley, supra note 1, at 914 n.50 (describing my view of federalism as part of the general scholarly neurosis characterized by fear of a revival of the concept).

10. See Ann Althouse, Enforcing Federalism After United States v. Lopez, 38 ARIZ. L. REV. 793, 801 (1996) [hereinafter Althouse, Enforcing Federalism] (arguing that federalism needs a set of institutional protections to preserve power on the local level); see also Ann Althouse, Variations on a Theory of Normative Federalism: A Supreme Court Dialogue, 42 DUKE L.J. 979, 982 (1993) (contrasting views on whether the individual or the community is the beneficiary of normative federalism). 
sort of devotion to federalism that does not seriously challenge national unity.

But Baker and Young openly, eagerly embrace not just federalism but "states' rights." Their use of the term "rights" is not accidental. The way they would treat states corresponds to the way American law treats individual human beings when it is said that they have rights. ${ }^{11}$ The law protects individual freedom of speech even though that freedom will be used by persons who have hateful, ugly, or disturbing things to say; the law, however, may justify this individual autonomy on the theory that, over time, good will emerge from the marketplace of ideas. ${ }^{12}$ By the same token, Baker and Young are willing to take the risk that some states might do bad things with their freedom..$^{13}$ They want protection of state autonomy and rely on a belief that in the long run what the states do with their independence will accrue to the good. Just as some First Amendment libertarians advocate a marketplace of ideas, Baker and Young might be said to advocate a marketplace of states, offering Americans a choice of fifty different cultures.

Let there be not only a diverse array of speech and a beneficial marketplace of ideas from which to choose, their argument goes, but also a diverse array of states, giving us a rich choice of places to live within the United States. Should the law respond positively to this idea of a marketplace of states? Should it protect the ability of states to produce different cultures in a manner similar to the way it protects the differences of opinion among individuals? One might well object to the use of the marketplace metaphor. Shopping in the marketplace of ideas differs dramatically from shopping in the marketplace of states: to acquire a new idea an individual need only think it, but to acquire a new political culture an individual must move to another state. "Vote with your feet" may be a good enough answer, at least to Baker and Young, but scholars must recognize that it is much

11. Baker \& Young, supra note 3, at 134-36.

12. See id. at 139-42 (contrasting the way that the guarantees of individual rights are embraced on principle despite their sometimes undesireable manifestations, while federalism provisions are not); see also Rosenberger v. Rector of the Univ. of Va., 515 U.S. 819, 831, 852 (1995) (finding the exclusion of religious viewpoints when non-religious viewpoints are permitted offensive to the First Amendment); McIntyre v. Ohio Elections Comm'n, 514 U.S. 334, 341, 342 (1995) (emphasizing that authors are free to distribute publications anonymously even if the messages are unpopular); Abrams v. United States, 250 U.S. 616, 630 (1919) (Holmes, J., dissenting) (stressing the need for vigilance "against attempts to check the expression of opinions" that society finds loathsome).

13. Baker \& Young, supra note 3, at 139. 
harder to change one's residence than to change one's mind. On the other hand, it can be argued that if one disapproves of one's local or state government, it is at least easier to participate in the process of changing policy at that level of government than at the national level. Most important, as Baker and Young argue, society loses something valuable when the law imposes national uniformity and displaces the diversity among the states and localities. To be sure, the harms attributable to nationwide uniformity of government policy cannot begin to compare to the evil of homogenizing human minds, but Baker and Young are right to worry about losing the diversity and vitality that the processes of state and local government have to offer. ${ }^{14}$

Although a state is not a being capable of expression, individuals within states find expression through the institutions of state and local government. Of course, the national government provides a channel for the expression of individual preferences as well, but favoring individual expression at the lower levels of government gives individuals a stronger voice and a greater incentive to participate. It also produces a greater variety of expression and a rich dialogue about policy that cannot occur at the national level.

This argument for diversity—at least in cases in which uniformity is not necessary-is a strong one, yet its appeal inevitably will vary depending on how one answers the normative question. As long as Americans fear that states will do too much harm and too little good if left to their own devices, they are likely to prefer not states' rights, but, at most, a flexible, pragmatic federalism.

\section{The Problem With the “Double Standard” AtTACK}

Baker and Young do not moderate their position to ensure that the states only do good with their independence: they prefer a wholehearted recognition of independence, comparable to the independence accorded the human individual. They criticize the use of different levels of judicial scrutiny for different parts of the Constitutionwhat they call a "double standard" of judicial review. ${ }^{15}$ In their view, a single methodology ought to govern constitutional interpretation, at least until there is good reason to adopt variable methodologies; anyone who argues for shortchanging some parts of the Constitution

14. See id. at 139, 153-54 (discussing the freedom that flows from being able to choose between states with varying regulatory schemes).

15. E.g., id. at $77,80-85$. 
bears the burden of proof. For Baker and Young, something more than mere backward-looking fear is needed to meet that burden.

Because they argue that federalism should be enforced according to the same methodology used to enforce individual rights, ${ }^{16}$ Baker and Young have good reason to use the term "states' rights." Their demand for justification of the double standard should speak to those who defend judicial restraint for federalism claims while supporting judicial activism in the context of individual rights. ${ }^{17}$ But their demand does not speak so clearly to those who purport to adopt a single methodology, those who never pose in the mantle of restraint. That is, the "double standard" challenge will not faze those whose failure to give much meaning to the structural provisions of the Constitution is not attributed to judicial restraint, but to a straightforward determination that the relevant constitutional provisions have a very narrow scope. For example, it is not uncommon for judges to look at the Tenth Amendment and to conclude that it adds nothing to the basic enumeration of powers in the original Constitution; then, by interpreting Congress's powers very broadly, these judges find little or nothing reserved to the states. ${ }^{18}$ Judges who do not perceive the Tenth Amendment as an embodiment of rights will feel invulnerable to the "double standard" attack; their defense is that they have consistently

16. Thus, Baker and Young elegantly respond to Justice Souter's professed incapacity to draw the lines needed to enforce federalism-based limits by referring to Souter's own elaborate defense of common law methodology in cases requiring difficult constitutional line-drawing in Washington v. Glucksberg, 521 U.S. 702, 756 (1997). Baker and Young refer in particular to Justice Souter's justification of judicial review in substantive due process cases, based on Justice Harlan's framework in Poe v. Ullman, 367 U.S. 497, 522 (1961) (Harlan, J., dissenting). See Baker \& Young, supra note 3, at 89-94.

17. See, e.g., United States v. Morrison, 529 U.S. 598, 628 (2000) (Souter, J., dissenting) (deferring to Congress's judgment about the reach of the commerce power); United States v. Lopez, 514 U.S. 549, 603, 613-14 (1995) (Souter, J., dissenting) (deploring judicial activism and advocating deference to implicit congressional judgment that gun possession falls within the commerce power); JESSE H. CHOPER, JUdICIAL REVIEW AND THE NATIONAL POLITICAL PROCESS 175, 263 (1980) (recommending activism with respect to individual rights and restraint with respect to the structural aspects of constitutional law).

18. See, e.g., Morrison, 529 U.S. at 660 (2000) (Breyer, J., dissenting) ("We live in a Nation knit together by two centuries of scientific, technological, commercial, and environmental change. Those changes, taken together, mean that virtually every kind of activity, no matter how local, genuinely can affect commerce, or its conditions, outside the State-at least when considered in the aggregate.") (citation omitted); United States v. Lopez, 514 U.S. 549, 620 (1995) (Breyer, J., dissenting) ("Having found that guns in schools significantly undermine the quality of education in our Nation's classrooms, Congress could also have found, given the effect of education upon interstate and foreign commerce, that gun-related violence in and around schools is a commercial, as well as a human, problem."). 
used a generous approach to interpreting both individual rights and congressional powers.

Justice Breyer's dissenting opinion in United States v. Lopez, ${ }^{19}$ as contrasted to Justice Souter's dissenting opinion, ${ }^{20}$ illustrates that there are two approaches to validating Congress's power. Justice Souter heartily embraced " $[\mathrm{t}]$ he practice of deferring to rationally based legislative judgments." ${ }^{21}$ In Souter's writing, the " "paradigm of judicial restraint", 22 and "respect for the institutional competence of the Congress",23 appear indispensable to keeping the Court from slipping back into the deplorable "old pitfalls" of the Lochner era. ${ }^{24}$ By contrast, Justice Breyer's Lopez dissent only mentions judicial restraint:

[T] he Constitution requires us to judge the connection between a regulated activity and interstate commerce, not directly, but at one remove.... [T] he specific question before us, as the Court recognizes, is not whether the "regulated activity sufficiently affected interstate commerce," but, rather, whether Congress could have had "a rational basis" for so concluding.

But immediately after acknowledging the presence of this rational basis test in the Commerce Clause case law, Justice Breyer hedged:

I recognize that we must judge this matter independently. "[S]imply because Congress may conclude that a particular activity substantially affects interstate commerce does not necessarily make it so." ${ }^{26}$

He thus appeared to say, "I do not need to stand 'at one remove'; I do not need to constrain my powers of perception or shrink with modesty about lack of judicial expertise to perceive that Congress has ample power to enact this sort of statute." Accordingly, Justice

19. 514 U.S. 549, 615 (1995) (Breyer, J., dissenting).

20. Id. at 603 (Souter, J., dissenting). Justices Souter and Breyer joined each other's opinions, so the point here is not that the two approaches are mutually exclusive.

21. Id. at 604 .

22. Id. (quoting FCC v. Beach Communications, Inc., 508 U.S. 307, 314 (1993)).

23. Id.

24. Id. at 607-08 (citing Lochner v. New York, 198 U.S. 45 (1905)). Similarly, in Morrison, Justice Souter swathes his dissenting opinion in the rhetoric of restraint: "The business of the courts is to review the congressional assessment, not for soundness but simply for the rationality of concluding that a jurisdictional basis exists in fact." United States v. Morrison, 529 U.S. 598, 628 (2000).

25. Lopez, 514 U.S. at 616-17 (Breyer, J., dissenting) (citations omitted).

26. Id. at 617 (quoting Hodel v. Va. Surface Mining \& Reclamation Ass'n, Inc., 452 U.S. 264, 311(1981) (Rehnquist, J., concurring)). 
Breyer proceeded not just to answer the "specific question" whether Congress had a rational basis for finding that gun possession near schools had a substantial effect on interstate commerce, but to directly conclude that " $\mathrm{t}]$ he empirical evidence... unmistakably documents the special way in which guns and education are incompatible." 27

Were Baker and Young's argument to convince Justice Breyer that invocations of judicial restraint marred his writing, he would need to delete only a few marginal passages from his dissent. His forceful, "unmistakable" assessment of the evidence would remain and fully support his ultimate conclusion. It might take more to convince Justice Souter of the evils of invoking judicial restraint in this context, but I would predict nevertheless that if Baker and Young's argument caused him to see judicial restraint as an unprincipled use of a double standard, Justice Souter would join Justice Breyer's newly streamlined approach to writing opinions. The conclusion would remain the same. Whether they scrutinize Congress's power closely or "at one remove," they will perceive great breadth.

To change their conclusion and not merely their rhetoric, it is necessary to produce change at a deeper level, the level of beliefs about the relative values of state autonomy and national power. Questions about the normative value of federalism are unavoidable. To understand what is going on in these decisions, scholars need to think hard about what motivates Americans or should motivate them to give broad meaning to the parts of the Constitution that favor the states or to give something less than broad meaning to the parts of the Constitution that empower the federal government. Americans can only be convinced to adopt a states' rights model if they feel secure that the states are more likely to do good from a position of independence than to backslide into the evils of the past or to dream up new evils in the future.

\section{PopPING THE GARCIA BUBBLE}

Baker and Young devote much of their argument to contesting the position, taken in Garcia v. San Antonio Metropolitan Transit Authority, ${ }^{28}$ that the structure of the national government provides an

27. Id. at 624 .

28. 469 U.S. 528 (1985). 
adequate safeguard to the states. ${ }^{29}$ They think the proponents of federalism would have greater success if they put more effort into refuting the "political safeguards" credo. Although I think it is unlikely that many seriously believe that political checks adequately safeguard federalism, ${ }^{30}$ it is surely valuable to have Baker and Young's beautifully articulated explanation of why such a belief would be wrong. ${ }^{31}$ Their article is especially helpful in its explanation of the "horizontal" problem that undermines the political safeguards argument: that the states with majority power in Congress can exploit the mechanisms of the national government for the purpose of imposing their choices on the states with minority power. ${ }^{32}$ Because of the horizontal problem, Baker and Young argue, it is not enough that the states are represented in the federal government.

Even someone who believes that state governments find perfect expression of their positions through their states' representatives in Congress should see the horizontal problem as a reason to reject the safeguards argument. The preferences of the states with majority power in Congress will prevail, forcing the other states to accept policies the majority-power states already were able to enforce within their own borders. Baker and Young contend that the states with majority power are simply using Congress to expand their preferences beyond their borders onto the other states that do not share that preference. ${ }^{33}$ It is dysfunctional for majority-power states to force their policies on dissenting states through congressional action; these states already enjoy their preferred polices and remain unaffected by the policies of other states. Most outrageously, if Congress acts under the Spending Power, some states extract a cash windfall for doing

29. See generally Baker \& Young, supra note 3, at 106-33.

30. I tend to think that Garcia supporters favor limiting the states to the protection they can extract from Congress because they see little reason to protect the states at all or because they favor congressional policymaking over state interests. Thus, once again, the unavoidability of the normative question. If one thinks the states are unlikely to do good with their autonomy and might do harm, one wants Congress in a position to control them, and one sees no sacrifice in exposing their experimentation to congressional squelching.

31. See Baker \& Young, supra note 3, at 112-28 (discussing the problems of vertical and horizontal aggrandizement).

32. Id. at $117-28$. It is interesting to note that the states with majority power do not necessarily represent a majority of the people, largely because of the structure of the Senate. This fact makes the horizontal problem worse. Ironically, the equal representation of the states in the Senate is supposed to be one of the primary "safeguards" Congress offers the states.

33. Id. at $117-18$. 
what they wanted to do anyway and tap federal funds for the purpose of pressuring the other states to abandon their own preferences.

I would argue, however, that imposing the choice of the majority is justified, despite the horizontal problem, where there is some additional reason for a matter to be dealt with on a national level. There are some policies that do not work unless they are adopted by all, such as the national effort to stabilize prices through production controls at issue in Wickard v. Filburn. ${ }^{34}$ States attempting to achieve such an end independently would fail, as producers in other states would take advantage of the opportunity to increase production. Similarly, without a national drinking age of twenty-one, ${ }^{35}$ a state that chose a lower drinking age than its neighbors would tempt younger drinkers to drive across state borders, creating hazards beyond its borders. There may be other reasons to impose the will of the majority of states on all the states. The Civil Rights Act of 1964, upheld by the Supreme Court in its most expansive interpretations of the Commerce Clause, ${ }^{36}$ embodied an important national commitment to equality that overshadowed the interest in state individualism.

Again, I would argue, there is no escape from the normative question. In order to defeat the power of the political safeguards argument, it is not enough to show that the safeguards do not work. To argue successfully that courts should add to whatever safeguards already inhere in the political process, one must convince people that states, given more autonomy than the political process gives them, will use that autonomy to pursue worthy goals, rather than to shield

34. 317 U.S. 111 (1942). By contrast, the Gun-Free School Zones Act, struck down in United States v. Lopez, 514 U.S. 549 (1995), did not involve a matter that needed to be dealt with by a uniform rule; indeed, the diverse solutions already being pursued by the states exemplified the states as laboratories of democracy. See id. at 568, 581-82 (Kennedy, J., concurring) (listing various approaches for remedying the school violence problem underway in various localities). Federal law clumsily intruded with harsh criminal penalties where some states were experimenting with family- or community-based intervention. See Althouse, Enforcing Federalism, supra note 10, at 819-20 (characterizing the Gun-Free School Zones Act as interfering with the preferences of the states that chose to deal with the problems of juveniles in a more benevolent way and as unnecessary to the states that preferred-and could enact-harsh criminal penalties). There was no good reason to impose the criminal model everywhere and displace preferences that were tailored to local conditions and preferences and that reflected a more moderate, benevolent attitude toward children.

35. See South Dakota v. Dole, 483 U.S. 203, 206 (1987) (allowing Congress to impose a minimum drinking age on the states as a condition of receiving federal funds).

36. Katzenbach v. McClung, 379 U.S. 294, 304 (1964) (holding that, under the Commerce Clause, Congress had the power to bar race discrimination in a local restaurant); Heart of Atlanta Motel, Inc. v. United States, 379 U.S. 241, 258-59 (1964) (holding that, under the Commerce Clause, Congress had the power to bar race discrimination in a local hotel). 
deleterious behavior. To argue for the judicial protection of state interests, beyond the safeguards that already inhere in the political process, one must convince people that there is something worth safeguarding and that the new judicial safeguards will not create new problems. One must show that there are great benefits emanating from the separate functioning of the states, benefits that make citizens willing to take on the burden of accomplishing some widely shared goals with state-by-state, patchwork efforts instead of straightforward and efficient federal statutes. ${ }^{37}$

\section{CONCLUSION}

To embrace Baker and Young's argument, one must abandon the fear of the negative side of state autonomy. Yet it is hard to conceive of the sort of evidence that would overcome this fear. Would masses of historical, sociological, and cultural material help? Baker and Young do not attempt to prove that state autonomy will produce more good than harm. ${ }^{38}$ At most, they reassure citizens that individual rights will provide safeguards against the bad state. ${ }^{39}$ If states were really to attempt to revert to their old prejudiced ways, Baker and Young assert, constitutional rights would bar their way. ${ }^{40}$ There is no need therefore to disempower the states, because individual rights block the paths toward the outcomes Americans fear. In other words, to return to Rubin and Feeley's metaphor, states' rights opponents deserve the diagnosis of post-traumatic stress syndrome: their fears

37. Baker and Young notably take the position that the states' rights approach expresses the reality that there is no one right answer about most of the things that become the subject of law. Baker \& Young, supra note 3, at 150-51. This reality justifies diversity. To the extent that we do not believe that there is a single and discernable truth, we should resist national uniformity and value diversity, Baker and Young wisely argue. Yet perhaps those who tend not to see one right answer ought also to refrain from taking a rights-based approach toward federalism questions. It is not enough to say that the normative federalism approach requires us to decide when federalism serves the good, and the point is that one cannot say definitively what is good. To defer to the state in normative federalism analysis is to say that this is an area where it is good to preserve diversity. By the same token, one withholds deference when it is good to have one rule. This is not to argue for a uniform national rule whenever it becomes possible to ascertain precisely what the best rule is. The point is that there are some policies that must be imposed uniformly if they are to work at all. To leave some matters to state-by-state regulation is to make some kinds of regulation beyond the reach of any government. The idea of normativity thus ties to the relative values of diversity and uniformity, not to the comparative values of particular policies.

38. Id. at 143 .

39. Id. at $147-49$.

40. Id. 
are echoes of the past that lack any present-day cause. Although there is no danger in giving power to the states, Americans (traumatized by the past) deny themselves the benefits that revitalized state and local government has to offer.

It seems quite unlikely, though, that the Supreme Court will heartily embrace states' rights, in the Baker-Young manner. ${ }^{41}$ Rubin and Feeley were right in their assessment that all of the talk about federalism has had very little effect. The Court's federalism doctrine, despite the outcry it provokes, ${ }^{42}$ is quite modest. Although the Court struck down a provision of the Violence Against Women Act that invoked the commerce power to create a federal tort that one individual could assert against another for conduct that was not "commercial" activity, ${ }^{43}$ the Court recently deflected an opportunity to condemn the federalization of local crimes, ${ }^{44}$ thwarted the attempt of one state to have an effect on human rights violations in a foreign

41. Oddly, Baker and Young's active embrace of states' rights does not include state sovereign immunity. They reject Seminole Tribe v. Florida, 517 U.S. 44 (1996), which denies Congress the power to abrogate state sovereign immunity using its Article I powers. Id. at 47. Although, under Garcia v. San Antonio Metropolitan Transit Authority, 469 U.S. 528 (1985), Congress is able to regulate the states, Seminole Tribe spares the states from lawsuits by individuals for retrospective relief. Forward-looking relief can be achieved by suing the individual who acts for the state, see Ex parte Young, 209 U.S. 123, 159-60 (1908), and enforcement, even retrospective enforcement, of federal law can be achieved through lawsuits brought by the United States. It is a mystery why the modest protection from accumulated liability that Seminole Tribe offers to the states should be the one effort in federalism enforcement that falls short in the Baker-Young states' rights scheme. I would think, however, that the states' rights position, as opposed to the normative federalism position that I have advocated, see Ann Althouse, The Alden Trilogy: Still Searching for a Way to Enforce Federalism, 31 RUTGERS L.J. 631, 653-60 (2000), should go even farther than Seminole Tribe and reject congressional abrogation of sovereign immunity altogether.

42. See, e.g., Marci A. Hamilton, The Elusive Safeguards of Federalism, 574 AnNALS AM. ACAD. POL. \& SOC. SCI. 93, 101 (2001) (concluding that, since the New Deal, Congress has assumed too much power, and that the Court should use judicial review to check this trend).

43. United States v. Morrison, 529 U.S. 598, 610-19 (2000). Although violence against women certainly has a substantial effect on commerce, for the reasons Justice Breyer makes plain in his dissenting opinion, the majority requires a less attenuated connection between the regulated act and the effect on commerce when the regulated act is not itself a commercial activity. This is consistent with the Court's treatment of the Gun-Free School Zones Act in Lopez: one could construct a causal chain connecting guns in schools to substantial effects on commerce, but the majority rejects attenuated causation because the possession of a gun is not itself a commercial activity. The majority has devised this doctrine in its attempt to impose some limit on the commerce power. See Ann Althouse, Inside the Federalism Cases: Concern About the Federal Courts, 574 Annals AM. ACAD. POL. \& SoC. SCI. 132, 137-39 (2001) (explaining that judicial deference on the part of the Supreme Court gave way in the face of congressional acts which displaced local decisionmaking with "self-serving political recognition").

44. See Jones v. United States, 529 U.S. 848, 852-57 (2000) (reading the statute narrowly to exclude arson of a private residence). 
country, ${ }^{45}$ rejected an attempt by one state to bar private associations from discriminating based on sexual orientation, ${ }^{46}$ and squelched a vigorous state experiment intended to open up political primaries. ${ }^{47}$ Of course, those last two state experiments would fail even under Baker and Young's states' rights approach because in both, the Court used individual rights to thwart the state's policy efforts.

The Court has resisted wholesale revision of the state-national balance. Sprinkled throughout the recent cases are concurring opinions written by Justice Thomas proposing a more comprehensive and more principled approach the Court might take in framing its federalism doctrine. ${ }^{48}$ But the majority opinions in the recent line of federalism cases have been written by the more moderate Justices O'Connor and Kennedy and, most recently, Chief Justice Rehnquist. These opinions reveal a Court engaged in an incremental hammeringout of doctrine, relying on narrow grounds for decisionmaking, such as construing a statute to avoid a constitutional question or reading a federal statute broadly and finding a state statute preempted. The Court has not moved toward the broader, more principled version of federalism propounded by Justice Thomas. Perhaps this is because the Court lacks a majority for that approach, but I tend to think that most of the federalism-enforcing Justices prefer to pause and give Congress and the states an opportunity to respond to the Court's signals. ${ }^{49}$

To use that federalism buzzword "experiment," one might say that the Court is experimenting with enforcing federalism: trying small steps, signaling to Congress to restrain itself, waiting to see how the little changes will play in practice ${ }^{50}$ or even in the legal academy. I

45. Crosby v. Nat'l Foreign Trade Council, 530 U.S. 363, 372-74 (2000) (finding that federal law preempted a state law prohibiting trade between state entities and the nation of Burma).

46. Boy Scouts of Am. v. Dale, 530 U.S. 640, 643 (2000).

47. Cal. Democratic Party v. Jones, 530 U.S. 567, 572-77 (2000) (holding that a "blanket primary" infringes on a political party's right of association under the First Amendment).

48. E.g., United States v. Lopez, 514 U.S. 549, 584-602 (1995) (Thomas, J., concurring) (suggesting that Congress lacks power to regulate matters that are not commercial but that have a "substantial effect" on commerce); Printz v. United States, 521 U.S. 898, 936-39 (1997) (Thomas, J., concurring) (same).

49. Alternatively, the Court may be engaged in something like the common law process that Baker and Young recommend. See supra note 16.

50. See Althouse, supra note 41, at 686-89 (construing the Court's sovereign immunity doctrine as designing a "test period," in which the states and Congress, operating under the new doctrine, will generate evidence about their relative capacities and predilections and will thus create the context for the Court's future decisions). 
tend to think that if, in the wake of decisions like Lopez $^{51}$ and United States v. Morrison, ${ }^{52}$ Congress continues to create more federal crimes and torts, or resorts to the spending power to get around limits on the commerce power, the Court may tighten restrictions one more notch, and then hold back and see how that development plays. I also think that the Court has an eye on the states, that it is waiting to see what the states do with their increased freedom. The more the states come forward with new ideas that prove successful and that contradict the fears that the states are bastions of local prejudice, the more likely the Court is to increase its protection of the states. That is, the Court's own doctrine may be designed to set up an experiment that will produce the evidence that shapes the mindset that the Court brings to its next set of federalism cases.

I have predicted that Baker and Young's states' rights approach will fail if they cannot convince people that state autonomy is a good thing, not to be feared. They have not tried to present historical, sociological, or other evidence capable of dissipating the fears they believe are groundless, and I doubt that they could. The specter of slavery, segregation, and racism is a powerful one and not easily conquered. The leap of faith their approach requires is one many will resist. In this light, the Court's incremental approach-the "experiment" described above-may begin to make sense. By testing the capacity of the states to produce a salutary diversity, an inviting marketplace, and the capacity of Congress to impose uniformity only when the benefits of uniformity outweigh diversity, the Court may generate the kind of evidence scholars feel secure enough to rely on as they struggle to answer the normative question.

Baker and Young would eschew this modest moderation. They want to speak the language of rights when they talk about federalism. They make a bold argument. Perhaps few will agree with them fully, but that does not mean that their brilliant argument lacks important and persuasive power. Their article makes the clear and forceful case for state autonomy, and everyone-including those who rankle at the mention of federalism and those who, like me, are the faint-hearted, neurotic federalists-ought to revel in the sheer range and depth of the challenge they make to our accustomed patterns of thinking.

51. United States v. Lopez, 514 U.S. 549 (1995).

52. 529 U.S. 598 (2000). 